\title{
The Comparison of Static Friction Coefficient on Wood Between the Combination of Wood-Metal Load System and Wood-Sand Load System
}

\author{
Utama Alan Deta ${ }^{1}$, Husni Mubarok ${ }^{2}$, Nadi Suprapto ${ }^{3}$, Alif Syaiful Adam ${ }^{4}$, Abd. Kholiq $^{5}$ \\ Physics Department \\ Universitas Negeri Surabaya \\ Surabaya, Indonesia \\ 11utamadeta@unesa.ac.id, ${ }^{2}$ husnimubarok254@gmail.com, ${ }^{3}$ nadisuprapto@unesa.ac.id, ${ }^{4}$ alifsyaifuladam@gmail.com \\ 5holiq@unesa.ac.id
}

\begin{abstract}
The aim of this research is comparison wood-metal load system (experiment 1) and wood-sand load system (experiment 2) to find the static friction coefficient on wood and the effectiveness of both systems. This study used a descriptive quantitative approach by using graphical analysis method, the manipulation variable is the mass of object $A\left(m_{\mathrm{A}}\right)$, whereas the response variable is the mass of load $\left(m_{L}\right)$ will move precisely. The result of this study are Wood-sand load system has better accuracy compared to the wood-metal load system, but requires a relatively long time. And from this experiments, it can provide an additional range of static friction coefficients reaching 0.55 using the lower limit in the physics for scientists and engineers textbook is 0.25 . So that the range of static friction coefficients of wood-onwood is $0.25-0.55$.
\end{abstract}

Keywords - static friction coefficient; comparison wood-metal load system; wood-sand load system

\section{INTRODUCTION}

Friction between two objects will make the microscopic connection at various points on the surface which resists their sliding on one and another $[1,2]$, as a figure 1 . The mechanism of sliding friction (a) the upper surface is sliding to the right over the lower surface in this enlarged view. (b) A detail, showing two spots where cold-welding has occurred. Force is required to break the welds and maintain the motion [3]. In general, many theories in physics are presented with the assumption without friction force, for example in free fall motion, piston motion, and simple pendulum oscillations. So, with the concept of friction is expected no one else considers the law of physics to be only applicable to the ideal in the laboratory field [4].

In order to achieve good results in conducting laboratory experiments, it's necessary several things that should be noted, one of which is the set of experimental tools that will be used [5]. Because with the existence of laboratory experiments it can improve the development of science $[6,7]$.

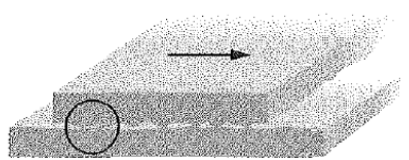

(a)

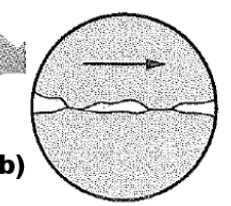

Fig. 1. The mechanism of sliding friction.

For determining the friction coefficient can be done in various ways, such as using graph analysis, microcontrollerbased applications [8, 9], Matlab program, compression-pullout test [10] and others. In addition to determining the coefficient of friction also to prove the law of frictional force proposed by Leonardo da Vinci, Amontons and Charles-Augustin Coulomb [11].

In his theory, Leonardo da Vinci revealed that there were three laws regarding frictional forces formulated in "law of dry friction" (a) Friction is proportional to weight, (b) friction does not depend on the contact area, and (c) the ratio of friction to weight is approximately $1 / 4$ [12]. The formula of friction force as Equation 1 (Static friction force) and Equation 2 (kinetic friction force), where $\mu_{\mathrm{s}}$ is the coefficient of static friction, $\mu_{\mathrm{k}}$ is the coefficient of kinetic friction, and $F_{N}$ is the magnitude of the normal force on the body from the surface [3].

$$
\begin{aligned}
& f_{s}=\mu_{s} F_{N} \\
& f_{k}=\mu_{k} F_{N}
\end{aligned}
$$

Then the theory of frictional force was developed by Amontons and Coulomb "the law of friction" [11, 13]. De Vinci emphasizes the weight while Amontons emphasizes the pressure. This classical formulation of the law of dry friction as it can be found in most contemporarily school books on 
physics. And the work of Amontons-Coulomb became widely known and had a significant impact on the engineering.

Until now, no tool can detect the friction coefficient of two surfaces correctly. Many variations of the friction coefficient can be found in various textbooks and research [1]. For example, the friction coefficient between wood-on-wood, the value range is $0.25-0.5[8,14]$.

This research emphasizes the effectiveness of using the load on laboratory experiments to determine the static friction coefficient of wood-on-wood using wood-metal load system and wood-sand load system.

\section{METHODS}

This research used a descriptive quantitative approach by using graphical analysis method [15] to explain the comparison of the static friction coefficient in the friction force experiment using wood-metal load system (experiment 1) and wood-sand load system (experiment 2). In this case, the manipulation variable is the mass of object $\mathrm{A}\left(m_{\mathrm{A}}\right)$, whereas the response variable is the mass of load $\left(m_{\mathrm{L}}\right)$ will move precisely, as in Fig. 2 and Fig. 3.

The method in this experiment is to put the object A (wood) on a track, made of wood. It becomes the object to determine the magnitude of the static friction coefficient, then connecting the object $\mathrm{A}$ to the load (metal) through a pulley with a thread. To manipulate the mass of object $\mathrm{A}\left(m_{\mathrm{A}}\right)$ is using the ballast metal that placed above it, then adjusts the mass of load $\left(m_{\mathrm{L}}\right)$ as the response variable, so that the mass of load $\left(m_{\mathrm{L}}\right)$ will cause object A $\left(m_{\mathrm{A}}\right)$ to move precisely. After that, the mass of the load $\left(m_{\mathrm{L}}\right)$ is measured. The load that used in this experiment 1 is using a metal plate with a mass of each metal plate approximately 1 gram.

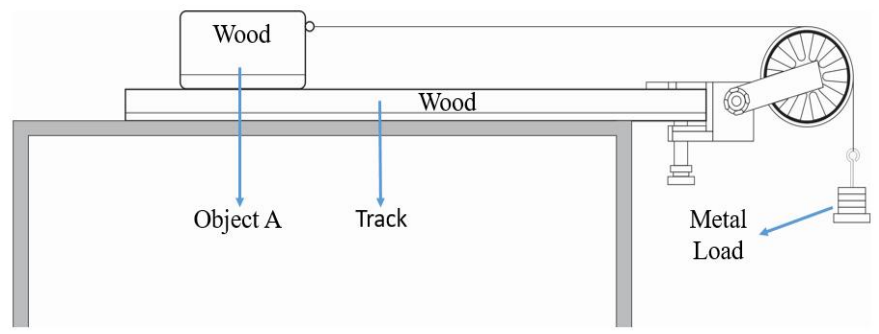

Fig. 2. Experiment 1 wood-metal load system

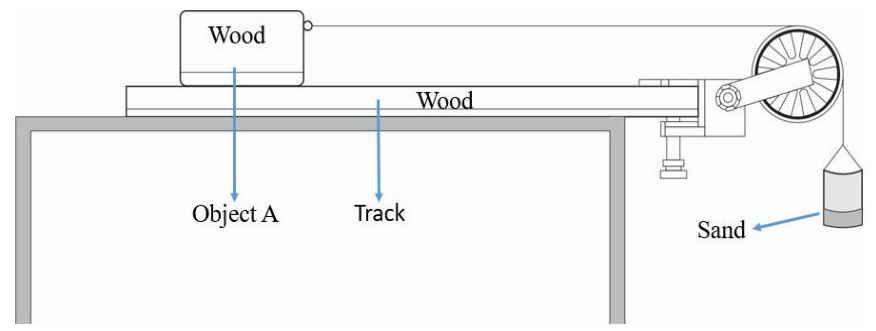

Fig. 3. Experiment 2 wood-sand load system
The method in experiment 2 is almost the same as experiment 1 , by replacing metal load using sand. After the experimental set is assembled, the sand is poured into the container $\left(m_{\mathrm{L}}\right)$ carefully until the mass of sand can move the object $\mathrm{A}\left(m_{\mathrm{A}}\right)$, then the mass of sand and the container be measured, to find how much the load (sand) is needed to make object A will move precisely.

\section{RESULTS}

The results of experiment laboratory to find the static friction coefficient between wood-on-wood using metal and sand loads are presented in Table 1 and Tables 2.

TABLE I. EXPERIMENT 1, THE STATIC FRICTION COEFFICIENT WOODMETAL LOAD SYSTEM

\begin{tabular}{|c|c|c|c|c|}
\hline No & $\begin{array}{l}\text { Mass of object A } \\
\qquad\left(m_{\mathrm{A}} \pm 0.05\right) \mathrm{g}\end{array}$ & $\begin{array}{l}\text { Massa of load } \\
\left(m_{\mathrm{L}} \pm 0.05\right) \mathrm{g}\end{array}$ & $\begin{array}{l}\text { Average of } \\
\text { load Mass } \\
\left(m_{\mathrm{L}} \pm 0.05\right) \mathrm{g}\end{array}$ & $\begin{array}{l}\text { static friction } \\
\text { coefficient }\left(\mu_{\mathrm{s}}\right)\end{array}$ \\
\hline 1 & \multirow{3}{*}{116.34} & 60.98 & \multirow{3}{*}{61.11} & \multirow{3}{*}{0.5253} \\
\hline 2 & & 60.98 & & \\
\hline 3 & & 61.38 & & \\
\hline 4 & \multirow{3}{*}{166.05} & 86.55 & \multirow{3}{*}{87.19} & \multirow{3}{*}{0.5251} \\
\hline 5 & & 86.55 & & \\
\hline 6 & & 88.48 & & \\
\hline 7 & \multirow{3}{*}{214.33} & 123.82 & \multirow{3}{*}{123.82} & \multirow{3}{*}{0.5777} \\
\hline 8 & & 123.82 & & \\
\hline 9 & & 123.82 & & \\
\hline 10 & \multirow{3}{*}{263.76} & 143.60 & \multirow{3}{*}{144.74} & \multirow{3}{*}{0.5488} \\
\hline 11 & & 146.30 & & \\
\hline 12 & & 144.33 & & \\
\hline 13 & \multirow{3}{*}{314.00} & 183.53 & \multirow{3}{*}{170.12} & \multirow{3}{*}{0.5418} \\
\hline 14 & & 163.42 & & \\
\hline 15 & & 163.42 & & \\
\hline
\end{tabular}

TABLE II. EXPERIMENT 2, THE STATIC FRICTION COEFFICIENT WOODSAND LOAD SYSTEM

\begin{tabular}{|c|c|c|c|c|}
\hline No & $\begin{array}{l}\text { Mass of object A } \\
\quad\left(m_{\mathrm{A}} \pm 0.05\right) \mathrm{g}\end{array}$ & $\begin{array}{l}\text { Massa of load } \\
\left(m_{\mathrm{L}} \pm 0.05\right) \mathrm{g}\end{array}$ & $\begin{array}{c}\text { Average of } \\
\text { load Mass } \\
\left(m_{\mathrm{L}} \pm 0.05\right) \mathrm{g}\end{array}$ & $\begin{array}{l}\text { static friction } \\
\text { coefficient }\left(\mu_{\mathrm{s}}\right)\end{array}$ \\
\hline 1 & \multirow{3}{*}{116.34} & 60.23 & \multirow{3}{*}{59.60} & \multirow{3}{*}{0.5123} \\
\hline 2 & & 60.36 & & \\
\hline 3 & & 58.20 & & \\
\hline 4 & \multirow{3}{*}{166.05} & 86.06 & \multirow{3}{*}{87.76} & \multirow{3}{*}{0.5285} \\
\hline 5 & & 89.18 & & \\
\hline 6 & & 88.05 & & \\
\hline 7 & \multirow{3}{*}{214.33} & 111.57 & \multirow{3}{*}{114.18} & \multirow{3}{*}{0.5327} \\
\hline 8 & & 116.82 & & \\
\hline 9 & & 114.14 & & \\
\hline 10 & \multirow{3}{*}{263.76} & 143.40 & \multirow{3}{*}{141.08} & \multirow{3}{*}{0.5349} \\
\hline 11 & & 137.41 & & \\
\hline 12 & & 142.42 & & \\
\hline 13 & \multirow{3}{*}{314.00} & 166.69 & \multirow{3}{*}{169.17} & \multirow{3}{*}{0.5387} \\
\hline 14 & & 171.38 & & \\
\hline 15 & & 169.43 & & \\
\hline
\end{tabular}

Based on the data in Table 1, it can be seen that from the five mass manipulations of object 1 , with three times repetition, get the varied results of the static friction coefficient is 0.52 0.58 , while Table 2 shows that the static friction coefficient is 0.51-0.54. In experiment 1 that use metal load have a range of static friction coefficient is 0.06 while in experiment 2 that use 
sand load have a range of static friction coefficient is 0.03 . This fact proves that the experiment 2 (wood-sand load system) has a more centralized result with a smaller range.

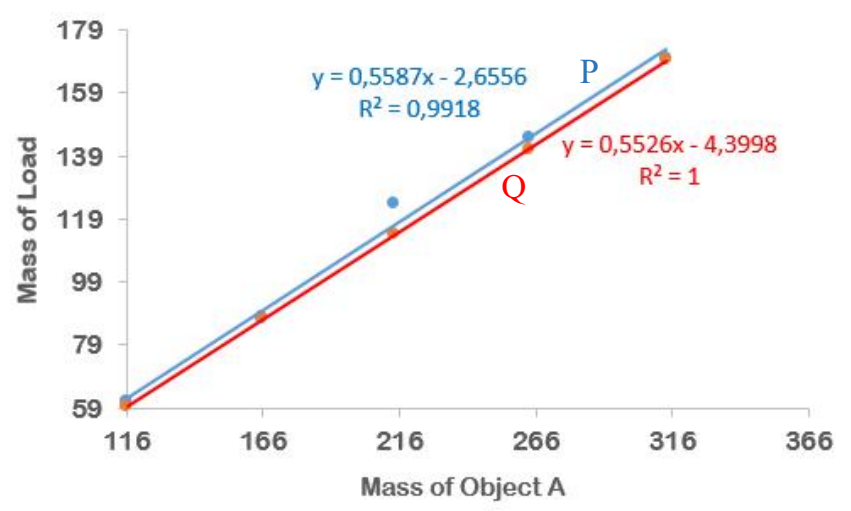

Fig. 4. The relationship between the mass of object A and mass of the load

The graph line equation in Figure 4 shows the relationship between the mass of object $\mathrm{A}\left(m_{\mathrm{A}}\right)$ and mass of the load $\left(m_{\mathrm{L}}\right)$. The blue line is the interpretation of Table 1 data, wood-metal load system, and the red line is the interpretation of Table 2 data, wood-sand load system. y-axis shows the load, and the $\mathrm{x}$-axis shows the mass of object A. For experiment 1 , the gradient of the blue line $(\mathrm{P})$ equation is 0.5587 . The slope shows that the value of the static friction coefficient and $\mathrm{R}^{2}$ shows the accuracy of this experiment [15]. The accuracy of experiment 1 is $99.18 \%$. For experiment 2 , the gradient of the red line $(\mathrm{Q})$ equation is 0.5526 . From the gradient show that the value of the static friction coefficient at wood-sand load system and the accuracy of experiment 2 is $100 \%$.

In both experiment models, have advantages and disadvantages. In experiment 1 , that used metal load can make practitioner easy using to get the data and need time faster than experiment 2 , because the metal used is in the form of plates and is in accordance with the place used. However, the resulting data has a lower accuracy compared to experiment 2 that used sand load. This can be seen from the range of the static friction coefficient and the accuracy level $\left(\mathrm{R}^{2}\right)$ based on Fig. 4, blue line (P) and red line (Q).

The disadvantage of using sand load requires better patience to put sand in the container to obtain good data, the mass of load (sand) used when object A will move precisely. Beside that, can make the floor dirty by sand if practitioner doesn't use it carefully.

TABLE III. COEFFICIENTS OF STATICS AND KINETIC FRICTION

\begin{tabular}{|l|c|c|}
\hline \multicolumn{1}{|c|}{ Materials } & $\begin{array}{c}\text { Coefficients of } \\
\text { Static Friction }\left(\mu_{\mathrm{s}}\right)\end{array}$ & $\begin{array}{c}\text { Coefficients of } \\
\text { kinetic Friction }\left(\mu_{\mathrm{k}}\right)\end{array}$ \\
\hline Steel on steel & 0.74 & 0.57 \\
\hline Aluminum on steel & 0.61 & 0.47 \\
\hline Copper on steel & 0.53 & 0.36 \\
\hline Rubber on concrete & 1.0 & 0.8 \\
\hline Wood on wood & $0.25-0.5$ & 0.2 \\
\hline Glass on glass & 0.94 & 0.4 \\
\hline Waxed wood on wet snow & 0.14 & 0.1 \\
\hline
\end{tabular}

\begin{tabular}{|l|c|c|}
\hline \multicolumn{1}{|c|}{ Materials } & $\begin{array}{c}\text { Coefficients of } \\
\text { Static Friction }\left(\mu_{\mathrm{s}}\right)\end{array}$ & $\begin{array}{c}\text { Coefficients of } \\
\text { kinetic Friction }\left(\mu_{\mathrm{k}}\right)\end{array}$ \\
\hline Waxed wood on dry snow & - & 0.04 \\
\hline Metal on metal (lubricated) & 0.15 & 0.06 \\
\hline Ice on ice & 0.1 & 0.03 \\
\hline Teflon on teflon & 0.04 & 0.04 \\
\hline Synovial joints in humans & 0.01 & 0.003 \\
\hline
\end{tabular}

From the graphs show that the value of static friction coefficient between wood-on-wood exceeds the range in the physics for scientists and engineers textbook, which has a value is $0.25-0.5$ as Table $3[8,14]$. Thus, based on this experiments, provides input that the range of static friction coefficients at wood-on-wood surface has a greater range. Using the lower limit of the physics for scientists and engineers textbook is 0.25 and using the upper limit based on this experiment is 0.55 . So the static friction coefficient of wood-on-wood is $0.25-0.55$.

In addition, for this experiment we must be careful on putting the object $\mathrm{A}$ on the track, so that there is no pressure from the hand when putting it, because it is hoped that only the weight of object A affects the friction between the surfaces. If there is another force or pressure from outside, can make difference microscopic connection between both surfaces (wood-on-wood) [1]. The variation mass of object A doesn't affect the magnitude of the static friction coefficient between the two surfaces, but affects the magnitude of frictional forces of both surfaces [12].

\section{CONCLUSION}

Wood-sand load system (experiment 2) has better accuracy compared to wood-metal load system (experiment 1), but requires a relatively long time and better patience. Based on this experiments, it can provide an additional range of static friction coefficients reaching 0.55 using the lower limit in the physics for scientists and engineers' textbook is 0.25 . So that the range of static friction coefficients of wood-on-wood is $0.25-0.55$.

\section{ACKNOWLEDGMENT}

This paper is the part of basic physics laboratory project at Physics Department Universitas Negeri Surabaya, Indonesia.

\section{REFERENCES}

[1] D. Tabor, Friction, Lubrication, and Wear. Source: Mechanical Design Handbook. Department of Physics, Cambridge University, 2006.

[2] B. Heimbecker, I. Nowikow, C. T. Howes, J. Mantha, B. P. Smith, H. M. van Bemmel, Physics Concepts and Connections, Book Two., Toronto: Irwin Publishing Ltd., 2002, pp. 44-47.

[3] D. Halliday, R. Resnick, J. Walker, Fundamentals of Physics, 9th ed., Jefferson City: RR Donnelley, 2011, pp.116-120.

[4] Y. Tiandho, "Misconception of friction in students university (miskonsepsi gaya gesek pada mahasiswa)," Jurnal Pendidikan Fisika dan Keilmuan (JPFK), vol. 4, pp. 1-9, 2018.

[5] M. Fitri, Hufri, Yohandri, ".making of static sheet weld coefficient determination systems on sliding fields microcontroller-based (pembuatan sistem penentuan koefisien gesek statis benda pada bidang miring secara digital berbasis mikrokontroler)." Pillar of Physics, Vol. 4, pp. 09-16, November 2014. 
[6] P. H. Winingsih, Hidayati, "Experimental of friction force to test the magnitude of static coefficients on wood-on-wood with matlab program (eksperimen gaya gesek untuk menguji nilai koefisien gesekan statis kayu pada kayu dengan program matlab)," Jurnal Science Tech., vol. 3, pp. 121-126, August 2017.

[7] H. Mubarok, A. Lutfiyah, A. Kholiq, N. Suprapto, N. P. Putri, "the performance assessment of undergraduate students in physics laboratory by using guided inquiry," Journal of Physics: Conf. Series, vol. 997, pp. $1-10,2018$.

[8] S. H. Lee, S. Harari, H. Wong, V. Kapila, "Friction experiment," Science and Mechatronics Aided Research for Teachers (SMART) The National Science Foundation (NSF) pp. 1-10, 2005.

[9] R. Hena, G. L. Doudic, B. Pilette C.. Even, J. M. Fischbach, C. A. M. Kikuchi "A study on kinetic friction: the Timoshenko oscillator," physics.ed-ph, pp. 1-15, October 2017.
[10] H. Kuwamura, "Coefficient of friction between wood and steel under heavy contact,” J. Struct. Constr. Eng., AIJ, vol. 666, pp. 1469-1478, August 2011.

[11] J. Wisniak, "Guillaume amontons," Revista Cenic Ciencias Químicas, Vol. 36, pp. 187-195, 2005.

[12] E. Popova1, V. L. Popov, "The research works of Coulomb and Amontons and generalized laws of friction," Short communication. Friction vol 3, pp. 183-190, 2015.

[13] J. R. Barber, "Multiscale surfaces and amontons' law of friction," Tribol Lett, vol. 49, pp. 539-543, 2013.

[14] R. A. Serway, J. W. Jewett, Physics for Scientists and Engineers, 6th ed., Cole: Thomson Brooks, 2004, pp. 131-137.

[15] S. Anggrayni, H. Mubarok, N. P. Putri, N. Suprapto, A. Kholiq, "The differences in analysing strategy of viscosity experiment between freshmen and laboratory assistant," Journal of Physics: Conf. Series, vol. 997, pp. 1-5, 2018. 